\title{
Effects of Spirulina platensis microalgae on antioxidant and anti-inflammatory factors in diabetic rats
}

This article was published in the following Dove Press journal: Diabetes, Metabolic Syndrome and Obesity:Targets and Therapy

\author{
Fariba Nasirian' \\ Masoumeh Dadkhah² \\ Nasrollah Moradi-kor ${ }^{3,4}$ \\ Zia Obeidavi ${ }^{5}$ \\ 'Department of Animal Sciences, \\ University of Birjand, Birjand, Iran; \\ ${ }^{2}$ Research Centers Development \\ and Coordination Office, Deputy \\ of Research \& Technology, Ardabil \\ University of Medical Sciences, \\ Ardabil, Iran; ${ }^{3}$ Research Centre of \\ Physiology, Faculty of Medicine, \\ Semnan University of Medical \\ Sciences, Semnan, Iran; ${ }^{4}$ Student \\ Research Committee, Faculty of \\ Medicine, Semnan University of \\ Medical Sciences, Semnan, Iran; \\ ${ }^{5}$ Student Research Committee, \\ Lorestan University of Medical \\ Sciences, Khorramabad, Iran
}

Objectives: Lipid peroxidation and hyperglycemia are common signs for diabetes. Natural antioxidants such as Spirulina platensis microalgae (SPM) may prevent lipid peroxidation and hyperglycemia. This study aimed to evaluate the effects of SPM on antioxidant and antiinflammatory in diabetic rats.

Materials and methods: Sixty-four rats were divided into eight groups $(n=8)$ and orally treated with 0, 10, 20 and $30 \mathrm{mg} / \mathrm{kg}$ body weight of SPM extract. Experimental groups included diabetic rats fed with 0 (DC), 10, 20 and $30 \mathrm{mg} / \mathrm{kg}$ SPM. Healthy rats were treated with $0 \mathrm{mg} / \mathrm{kg}$ SPM (HC), $10 \mathrm{mg} / \mathrm{kg} \mathrm{SPM}, 20 \mathrm{mg} / \mathrm{kg} \mathrm{SPM}$ and $30 \mathrm{mg} / \mathrm{kg} \mathrm{SPM}$. At the end of the trial, blood samples were collected and the plasma concentrations of trace minerals (TMs), biochemical parameters, and antioxidant enzymes in liver were evaluated. Aspartate aminotransferase (AST), alanine aminotransferase (ALT), TNF- $\alpha$ (tumor necrosis factor-alpha) and IL-6 (interleukin-6) were evaluated.

Results: Our findings showed that diabetes significantly lowered the plasma concentration of TMs and antioxidant enzymes in liver and also increased the levels of malondialdehyde, glucose, lipid profile, AST, ALT, TNF- $\alpha$ and IL-6 (DC vs HC). However, an oral supplement of SPM (20 and $30 \mathrm{mg} / \mathrm{kg}$ body weight) lowered levels of malondialdehyde level, glucose, lipid parameters, AST, ALT, TNF- $\alpha$ and IL-6. The same levels increased the plasma contents of zinc, iron, copper and selenium and activity of antioxidant enzymes $(P<0.05)$.

Conclusion: It can be concluded that diabetes decreases TM concentration and antioxidant enzymes and also increases lipid profile, glucose, AST, ALT, TNF- $\alpha$ and IL- 6 concentrations. Inclusion of SPM supplementing (20 and $30 \mathrm{mg} / \mathrm{kg}$ body weight) increased some TMs and antioxidant enzymes. SPM may provide TMs for synthesis of antioxidant enzymes which subsequently reduce lipid profile, glucose concentration and anti-inflammatory responses.

Keywords: antioxidant enzymes, diabetes, lipid profile, plasma selenium, Spirulina platensis

\section{Introduction}

Diabetes mellitus is a disease with multiple etiologies which has signs such as hyperglycemia and disturbances in carbohydrate, fat and protein metabolism. These disturbances are due to deficiencies in insulin secretion, insulin activity and/or both. In the long term, diabetes can cause problems such as disturbances in various organs. Some studies have shown a relation among trace elements (TMs), diabetes mellitus ${ }^{1}$ and changes in nutrient metabolism. ${ }^{2-5}$ Individuals with diabetes have reported to have inflammatory cytokines. ${ }^{6}$ Some TMs such as chromium, magnesium, vanadium, zinc, manganese, molybdenum and selenium can proteinate insulin activity. ${ }^{7}$ Zinc modulates insulin synthesis and storage and protects the structural integrity of insulin. ${ }^{3}$ Magnesium has
Correspondence: Nasrollah Moradi-kor Physiology Research Center, Semnan University of Medical Sciences and Health Services, Faculty of Medicine, Damghan Road, PO box 35195-I63, Semnan, Iran Tel +982333654207

Email moradikor@semums.ac.ir 
a critical role in phosphorylation reactions of glucose and its metabolism. Magnesium is involved in insulin resistance, carbohydrate tolerance, and dyslipidemia. ${ }^{8}$ Chromium as a trace mineral improves insulin activity through enhancing intracellular signaling. ${ }^{9}$ TMs are essential for some activities in the body and they affect the pathogenesis of diabetes mainly by their role in peroxidation and inflammation. In addition, it was reported that diabetes markedly elevated the serum level of glucose. ${ }^{10}$ Montilla et al ${ }^{10}$ stated that hyperglycemia can create injuries in tissues and the brain, which subsequently may increase glucose excretion. Hypertriglyceridemia and hypercholesterolemia are the most common lipid abnormalities in diabetes, ${ }^{11}$ and are related to glucose intolerance. ${ }^{12}$ Oxidative stress and reactive oxygen species production can decompose lipids and cause lipid peroxidation and lipolysis. Oxidative stress is dominant when antioxidant defense systems are defaulted. ${ }^{13}$ Previous studies have shown reduced antioxidant enzyme activity in diabetic animals compared with control animals. ${ }^{14}$ We believe that some functional foods, eg, Spirulina platensis microalgae (SPM), may improve levels of some TMs. ${ }^{15}$ SPM lipopeptides have a major role in physiological functions, eg, cytotoxic, antitumor, antiviral, antibiotic, antimalarial, antimycotic, multidrug resistance reversing, antifeedant, herbicide, and immunosuppressive factors. ${ }^{16} \mathrm{SPM}$, in a dose-dependent manner, decreased the metabolic activity of functional neutrophils, showing that SPM has anti-inflammatory activity. ${ }^{17}$ It contains more iron, magnesium, copper and zinc than other TMs. Antioxidants can help to prevent diabetes or alleviate the negative effects of diabetes on blood parameters and inflammatory phase. It is well accepted that antioxidants inhibit lipid peroxidation and subsequently alleviate harmful effects of diabetes on lipids and glucose. We hypothesized that diabetes reduces TMs, and SPM supplementing increases the required elements for synthesis of antioxidants; on the other hand, antioxidants can prevent lipid peroxidation and overproduction of pro-inflammatory cytokines. Thus, the present study was conducted to investigate the antioxidant mechanism of SPM on TMs and its effects on blood biochemical and antiinflammatory parameters.

\section{Materials and methods}

\section{Animals}

Sixty-four male Wistar rats, $200 \pm 20 \mathrm{~g}$ and 2.5 months of age at the start of the trial, were kept at room temperature $\left(25^{\circ} \mathrm{C}\right)$ and under a light cycle of 12 hours light/12 hours dark for 5 weeks. All rats had ad libitum access to a standard pellet diet (Javaneh Khorasan Company, Mashhad, Iran) and water.
The pellet composition was as follows: $20 \%$ protein, $3 \%$ fat, 4\% ash and 6\% fiber. All experiments were approved by the Ethical Committee of IAU University, Kerman, Iran (IAUKB-1105). The experiments were conducted in accordance with the National Institutes of Health Guide (NIH Publication No. 85-23, revised 1996) for the Care and Use of Laboratory Animals.

\section{Pilot study}

After 24 hours fasting, 36 Wistar rats were divided into four groups (each group six animals) and animals orally received $0.3 \mathrm{~mL}$ distilled water, and SPM extract (20, 40 and $60 \mathrm{mg} /$ $\mathrm{kg}$ of body weight). The animals were monitored in order to evaluate the behavioral responses, toxicity signs and mortality for 24 hours. No mortality or toxicity signs were observed; thus we used levels of 10,20 and $30 \mathrm{mg} / \mathrm{kg}$.

\section{Experimental treatments}

Streptozotocin (STZ; Sigma-Aldrich, St Louis, MO, USA) was used in order to induce diabetes mellitus in rats, as explained by Armstrong and Al-Awadi. ${ }^{19}$ Diabetes was induced by intraperitoneal injection of STZ (55 mg/kg BW). It was first dissolved in citrate buffer $(\mathrm{pH} 4.5,0.1 \mathrm{~mol} / \mathrm{L}$ trisodium citrate, $0.1 \mathrm{~mol} / \mathrm{L}$ citric acid). Diabetes was confirmed after measurement of blood glucose levels, three days after the STZ injection. Rats with plasma glucose level higher than $250 \mathrm{mg} / \mathrm{dL}$ were considered as diabetic. Glucose level was assessed using a kit from Pars Azmoon (Tehran, Iran). After induction of diabetes, rats were divided into two sections including healthy and diabetic. Animals were orally treated with microalgae (10, 20 and $30 \mathrm{mg} / \mathrm{kg}$ of body weight). Control rats were also treated with $0.3 \mathrm{~mL}$ distilled water. Each $10 \mathrm{mg}$ of microalgae was diluted in $2 \mathrm{~mL}$ distilled water and then orally administrated. Experimental treatments were as follows. Healthy rats fed with SPM at 10, 20 and $30 \mathrm{mg} / \mathrm{kg}$ of body weight were marked as SH10, SH20, and SH30, respectively. Rats treated with $\mathrm{SPM}$ at 10, 20 and $30 \mathrm{mg} / \mathrm{kg}$ of body weight were marked as SD10, SD20, and SD30 respectively. Two healthy control (HC) and diabetic control (DC) groups were also considered. Therefore, animals were grouped into eight groups with eight rats per group. The SPM was purchased from Ghazaye Sabze Khalij Company (Bandar Abbas, Iran). The chemical composition of SPM is presented in Table 1. Chemical analysis of the SPM was done using the Association of Official Analytical Chemists (AOAC) method. ${ }^{18}$ Calibrations of trace minerals were performed with a series of mixtures containing graded concentrations of standard solutions of the same trace mineral. 
Table I Chemical composition of SPM

\begin{tabular}{ll}
\hline Components & Amount \\
\hline Dry matter (\%) & 95 \\
Ether extract $(\%)$ & 5.3 \\
Crude protein (\%) & 61.8 \\
Crude fiber (\%) & 9.5 \\
Ash $(\%)$ & 6.9 \\
$\mathrm{Ca}(\mathrm{mg} / 100 \mathrm{~g})$ & 500 \\
$\mathrm{P}(\mathrm{mg} / 100 \mathrm{~g})$ & 800 \\
$\mathrm{Fe}(\mathrm{mg} / 100 \mathrm{~g})$ & 90 \\
$\mathrm{~K}(\mathrm{mg} / 100 \mathrm{~g})$ & 1,235 \\
$\mathrm{Mg}(\mathrm{mg} / 100 \mathrm{~g})$ & 195 \\
$\mathrm{Cu}(\mathrm{mg} / 100 \mathrm{~g})$ & 20 \\
$\mathrm{Zn}(\mathrm{mg} / 100 \mathrm{~g})$ & 15 \\
$\mathrm{Se}(\mathrm{mg} / 100 \mathrm{~g})$ & 1 \\
$\mathrm{Cr}(\mathrm{mg} / 100 \mathrm{~g})$ & 1 \\
\hline
\end{tabular}

Abbreviation: SPM, Spirulina platensis microalgae.

\section{Blood samples}

At 35 days of trials, all rats were anaesthetized and blood samples were collected from the tail vein in order to measure the blood biochemical parameters and TMs. The blood samples were transferred into tubes containing heparin for measurement of blood biochemical parameters and TMs, respectively. The samples were centrifuged at 2,000 $\mathrm{g}$ for 5 minutes and plasma was separated. Blood parameters were determined by the Pars Azmoon kit. The samples were analyzed using commercial kit (Pars Azmoon) in order to measure the triglycerides, glucose, cholesterol and low-density lipoprotein (LDL). Aspartate aminotransferase (AST) and alanine aminotransferase (ALT) were assessed by auto-analyzer apparatus (Gesan Production Srl, Campobello di Mazara (TP), Italy). The samples were evaluated for the concentration of TNF- $\alpha$ (tumor necrosis factor-alpha) and IL-6 (interleukin-6) by specified kits of Abcam (Cambridge, UK), as recommended by manufacturer's instructions. Levels of plasma TMs were evaluated by atomic absorption spectrophotometer. Calibrations of trace minerals were performed with a series of mixtures containing graded concentrations of standard solutions of the same trace mineral.

\section{Activity of antioxidant enzymes and malondialdehyde (MDA)}

After blood sampling, animals were anesthetized by ketamine. The liver was separated and liver tissues were washed in ice-cold $0.9 \%$ saline $(\mathrm{w} / \mathrm{v})$, then weighed and stored at $-70^{\circ} \mathrm{C}$. Activities of superoxide dismutase (SOD), glutathione peroxidase (GSH-Px) and catalase (CAT) and also levels of MDA were measured as previously explained by Bukan et al. ${ }^{14}$

\section{Statistical analysis}

The data were analyzed by GraphPad Prism statistical software (GraphPad Software, Inc., La Jolla, CA, USA) and the data were analyzed by one-way analysis of variance (ANOVA) with Dennett's multiple comparison posttest. Treated and non-treated rats in each section were compared by Dennett's multiple comparisons posttest. Healthy rats were compared with diabetic rats in the same group by Student's $t$-test. For example, control healthy rats were compared with control diabetic rats and data are presented in tables. The results are presented as mean $\pm \mathrm{SD}$. A value of $P<0.05$ was considered to be statistically significant.

\section{Results}

Our findings in Table 2 showed that diabetes reduced the plasma concentration of TMs $(P<0.05$ : DC vs HC), but oral supplementing with SPM (20 and $30 \mathrm{mg} / \mathrm{kg}$ body weight) significantly increased the plasma concentrations of zinc, iron, selenium and copper $(P<0.05)$. Treatment with SPM did not improve other TMs. The plasma concentrations of TMs were not influenced by SPM supplementing in healthy rats $(P>0.05)$. Results (Tables 3 and 4$)$ showed that diabetes significantly increased the plasma concentrations of glucose, triglycerides, cholesterol, LDL, ALT, AST, TNF- $\alpha$ and IL-6. However, rats treated with SPM $(20$ and $30 \mathrm{mg} / \mathrm{kg}$ body weight) showed the lower plasma concentrations of glucose, triglycerides, cholesterol, LDL, ALT, AST, TNF- $\alpha$ and IL-6 compared with DC. Our findings indicated that diabetes lowered activity of antioxidant enzymes and increased MDA levels compared with $\mathrm{HC}(P<0.05)$. Similar to the above findings, oral supplementing with SPM at levels of 20 and 30 $\mathrm{mg} / \mathrm{kg}$ body weight increased activity of antioxidant enzymes and lowered MDA levels $(P<0.05)$.

\section{Discussion}

Our findings showed that diabetes significantly lowered the plasma concentration of TMs. Comparing the data for $\mathrm{HC}$ and DC groups showed that diabetes decreases the plasma concentrations of TMs. The data for TMs were as follows: for zinc

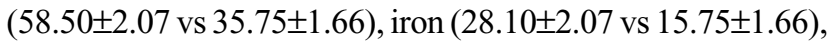

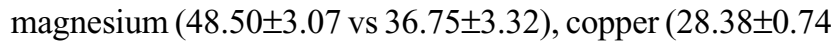
vs $16.50 \pm 1.85)$, selenium $(13.38 \pm 0.51$ vs $8.00 \pm 0.75)$, and chromium (23.38 \pm 0.75 vs $18.28 \pm 0.51)$. Studies have shown that deficiencies in zinc and chromium levels may cause glucose intolerance and insulin resistance..$^{20,21} \mathrm{Zinc}$ is an essential cofactor for SOD, which acts as an intracellular antioxidant enzyme. It has been suggested that pancreatic beta cells have low antioxidative enzyme activities which might be more sen- 
Table 2 Effect of SPM at different levels on TMs concentration ( $\mu \mathrm{mol} / \mathrm{L})$

\begin{tabular}{lllllll}
\hline & Zinc & Iron & Magnesium & Copper & Selenium & Chromium \\
\hline Groups & & & & & & \\
HC & $58.50 \pm 2.07_{a}$ & $28.10 \pm 2.07_{a}$ & $48.50 \pm 3.07_{a}$ & $28.38 \pm 0.74_{a}$ & $13.38 \pm 0.5 I_{a}$ & $23.38 \pm 0.755_{a}$ \\
SH10 & $57.38 \pm 1.40_{a}$ & $27.38 \pm 1.40_{a}$ & $47.38 \pm 1.40_{a}$ & $28.13 \pm 0.64_{a}$ & $13.38 \pm 0.53_{a}$ & $23.42 \pm 0.5 I_{a}$ \\
SH20 & $57.13 \pm 1.24_{a}$ & $27.13 \pm 1.24_{a}$ & $47.13 \pm 1.24_{a}$ & $27.50 \pm 0.53_{a}$ & $13.38 \pm 0.74_{a}$ & $23.25 \pm 0.7 I_{a}$ \\
SH30 & $58.00 \pm 1.19_{a}$ & $28.00 \pm 1.19_{a}$ & $48.00 \pm 1.19_{a}$ & $28.00 \pm 1.19_{a}$ & $13.38 \pm 0.62_{a}$ & $23.52 \pm 0.93_{a}$ \\
DC & $35.75 \pm 1.66_{c}$ & $15.75 \pm 1.66_{c}$ & $36.75 \pm 3.32_{b}$ & $16.50 \pm 1.85_{c}$ & $8.00 \pm 0.75_{c}$ & $18.28 \pm 0.5 I_{b}$ \\
SD10 & $36.75 \pm 1.38_{c}$ & $16.75 \pm 1.38_{c}$ & $35.25 \pm 4.86_{b}$ & $17.25 \pm 1.28_{c}$ & $8.20 \pm 0.7 I_{c}$ & $18.78 \pm 0.42_{b}$ \\
SD20 & $45.38 \pm 1.9 I_{b}$ & $23.75 \pm 1.90_{b}$ & $38.50 \pm 2.07_{b}$ & $22.50 \pm 1.30_{b}$ & $9.75 \pm 1.28_{b c}$ & $18.58 \pm 0.9 I_{b}$ \\
SD30 & $46.00 \pm 2.07_{b}$ & $25.00 \pm 3.38_{a}$ & $36.38 \pm 3.07_{b}$ & $23.75 \pm 1.75_{b}$ & $11.13 \pm 0.83_{b}$ & $13.38 \pm 0.5 I_{b}$ \\
$P$-value & $* * *$ & $* * *$ & $* * *$ & $* * *$ & $* * *$ & $* * *$ \\
\hline
\end{tabular}

Notes: Subscripts $(a-c)$ show significant differences among groups per column and ${ }^{* * *}$ shows significant differences at $P<0.00$ I.

Abbreviations: SPM, Spirulina platensis microalgae; TM, trace minerals.

Table 3 Effect of SPM at different levels on some lipid profiles and glucose concentration $(\mathrm{mg} / \mathrm{dL})$ and liver enzymes (U/L)

\begin{tabular}{|c|c|c|c|c|c|c|}
\hline & Triglycerides & Cholesterol & LDL-C & Glucose & AST & ALT \\
\hline \multicolumn{7}{|c|}{ Groups } \\
\hline $\mathrm{HC}$ & $38.70 \pm 3.07_{c}$ & $70.15 \pm 8.50_{c}$ & $32.60 \pm 5.07_{c}$ & $135.20 \pm 1 \mid .50_{c}$ & $98.20 \pm 11.50_{c}$ & $85.20 \pm 7.50_{c}$ \\
\hline SHIO & $39.38 \pm 2.45_{c}$ & $68.20 \pm 7.40_{c}$ & $34.50 \pm 3.40_{c}$ & $141.20 \pm 12.50_{c}$ & $97.10 \pm 10.50_{c}$ & $83.20 \pm 5.15_{c}$ \\
\hline SH2O & $37.23 \pm 2.24_{c}$ & $69.50 \pm 6.50_{c}^{c}$ & $35.50 \pm 2.44_{c}$ & $139.80 \pm 10.90_{c}$ & $98.10 \pm 10.50_{c}$ & $82.10 \pm 7.15_{c}$ \\
\hline SH30 & $38.20 \pm 2.29_{c}$ & $67.50 \pm 5.15_{c}$ & $38.00 \pm 3.55_{c}$ & $135.70 \pm 9.40_{c}$ & $99.10 \pm 11.50_{c}$ & $84.40 \pm 9.15_{c}$ \\
\hline DC & $68.78 \pm 4.76_{a}$ & $108.5 \pm 10.66_{a}$ & $65.10 \pm 5.3 \mathrm{I}_{\mathrm{a}}$ & $279.00 \pm 18.40 \mathrm{a}$ & $310.10 \pm 17.50 \mathrm{a}$ & $145.40 \pm 12.14$ \\
\hline SDIO & $66.75 \pm 3.38_{a}$ & $99.50 \pm 9.6 \mathrm{I}_{\mathrm{a}}$ & $63.21 \pm 3.66_{a}$ & $269.50 \pm 14.50_{a}$ & $298.10 \pm 17.50$ & $149.40 \pm 9.14_{a}$ \\
\hline SD20 & $55.38 \pm 2.90_{b}^{a}$ & $70.50 \pm 7.10_{b}^{a}$ & $45.50 \pm 3.07_{b}$ & $205.20 \pm 15.70_{b}$ & $265.10 \pm 15.50_{b}^{\circ}$ & $119.40 \pm 9.14_{b}^{\circ}$ \\
\hline SD30 & $\begin{array}{l}54.10 \pm 2.07_{\mathrm{b}}^{\circ} \\
* * *\end{array}$ & $\begin{array}{l}68.10 \pm 5.15_{b}^{b} \\
* * *\end{array}$ & $\begin{array}{l}42.6 \mathrm{I} \pm 5.07_{\mathrm{b}} \\
* * *\end{array}$ & $\begin{array}{l}195.50 \pm \mathrm{I} 1.50_{\mathrm{b}}^{\circ} \\
* * *\end{array}$ & $\begin{array}{l}268.10 \pm 17.30_{b}^{\circ} \\
* * *\end{array}$ & $\begin{array}{l}121.40 \pm 7.14_{\mathrm{b}}^{\circ} \\
* * *\end{array}$ \\
\hline
\end{tabular}

Notes: Subscripts (a-c) show significant differences among groups per column and $* * *$ shows significant differences at $P<0.00$ I.

Abbreviations: SPM, Spirulina platensis microalgae; TM, trace minerals; LDL, low-density lipoprotein; AST, aspartate aminotransferase; ALT, alanine aminotransferase.

Table 4 Effect of SPM at different levels on liver SOD (U/mg protein), GSH-Px (U/mg protein), CAT (K/mg protein), MDA levels (nmol/g tissue) and pro-inflammatory cytokines $(\mathrm{pg} / \mathrm{mL}$ )

\begin{tabular}{lllllll}
\hline & SOD & GSH-Px & CAT & MDA & TNF- $\alpha$ & IL-6 \\
\hline Groups & & & & & & \\
HC & $30.50 \pm 2.25_{a}$ & $10.50 \pm 1.50_{a}$ & $0.34 \pm 0.05_{a}$ & $22.50 \pm 1.50_{c}$ & $5.10 \pm 0.50_{c}$ & $4.50 \pm 0.40_{c}$ \\
SH10 & $29.45 \pm 1.45_{a}$ & $11.20 \pm 1.40_{a}$ & $0.33 \pm 0.06_{a}$ & $21.50 \pm 1.70_{c}$ & $5.30 \pm 0.60_{c}$ & $4.80 \pm 0.50_{c}$ \\
SH20 & $28.25 \pm 1.25_{a}$ & $10.50 \pm 1.50_{a}$ & $0.34 \pm 0.02_{a}$ & $23.50 \pm 1.90_{c}$ & $5.20 \pm 0.15_{c}$ & $5.10 \pm 0.50_{c}$ \\
SH30 & $28.80 \pm 1.30_{a}$ & $10.80 \pm 1.10_{a}$ & $0.35 \pm 0.05_{a}$ & $24.10 \pm 2.40_{c}$ & $5.10 \pm 0.4_{c}$ & $5.50 \pm 1.00_{c}$ \\
DC & $21.80 \pm 2.75_{c}$ & $7.50 \pm 1.50_{b}$ & $0.19 \pm 0.01_{c}$ & $29.50 \pm 2.40_{a}$ & $10.50 \pm 0.50_{a}$ & $10.50 \pm 1.00_{a}$ \\
SD10 & $22.75 \pm 2.35_{c}$ & $8.10 \pm 0.90_{b}$ & $0.18 \pm 0.04_{c}$ & $28.70 \pm 1.50_{a}$ & $12.30 \pm 0.70_{a}$ & $9.60 \pm 1.30_{a}$ \\
SD20 & $26.45 \pm 1.90_{b}$ & $9.50 \pm 2.10_{a}$ & $0.26 \pm 0.04_{b}$ & $25.50 \pm 1.10_{b}$ & $8.50 \pm 0.50_{b}$ & $7.50 \pm 1.10_{b}$ \\
SD30 & $26.40 \pm 1.50_{b}$ & $10.50 \pm 0.90_{a}$ & $0.27 \pm 0.02_{b}$ & $25.10 \pm 0.90_{b}$ & $8.10 \pm 0.70_{b}$ & $7.50 \pm 0.80_{b}$ \\
$P$-value & $* * *$ & $* * *$ & $* * *$ & $* * *$ & $* * *$ & $* * *$ \\
\hline
\end{tabular}

Notes: Subscripts (a-c) show significant differences among groups per column and $* * *$ shows significant differences at $P<0.00$ I.

Abbreviations: SOD, superoxide dismutase; GSH-Px, glutathione peroxidase; CAT, catalase; MDA, malondialdehyde; TNF- $\alpha$, tumor necrosis factor-alpha.

sitive to free radicals, especially in zinc deficiency. ${ }^{22}$ Similarly, chromium has a role as a modulator in diabetes, ${ }^{23}$ glucose intolerance, ${ }^{24}$ and corticosteroid-induced diabetes. ${ }^{25}$ Magnesium is a trace element involved in glucose homeostasis, so there is a positive correlation between magnesium and glucose metabolisms. Magnesium has an important role in insulin action, and insulin stimulates magnesium uptake in insulin-sensitive tissues. Intracellular magnesium deficiency may affect the development of insulin resistance and alter the glucose entry into the cell. Magnesium is required for both proper glucose utilization and insulin signaling. ${ }^{26}$ Metabolic alterations in cellular magnesium, which may play the role of a second messenger for insulin action, contribute to insulin resistance. ${ }^{26,27}$ Selenium plays a main role in the antioxidant system by participation in glutathione peroxidases, thioredoxin reductase, and iodothyronine deiodinase. In view of 
its important function in protection against oxidative stress, selenium was suggested to play a protective role against diabetes. ${ }^{28,29}$ All the mentioned studies clearly state modulation of TMs in diabetes. Our findings also showed decreased levels of TMs during diabetes. As mentioned, TM deficiency influences diabetes mellitus, but TMs may help patients with diabetes mellitus. However, oral supplementing with SPM (20 and 30 $\mathrm{mg} / \mathrm{kg}$ body weight) increased the plasma concentrations of zinc, iron, copper and selenium. The reason why SPM at high levels increases levels of zinc, iron, copper and selenium is unknown. SPM may help to more absorption of TMs which may increase TMs concentration in plasma.

Diabetes increased the plasma concentrations of cholesterol, triglycerides, LDL-C and glucose. Comparing the data for $\mathrm{HC}$ and $\mathrm{DC}$ shows the differences clearly. The data were as follows: for cholesterol $(70.15 \pm 8.50 \mathrm{vs} 108.5 \pm 10.66)$, tri-

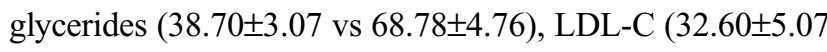
vs $65.10 \pm 5.31)$, glucose $(135.20 \pm 11.50$ vs $279.00 \pm 18.40)$,

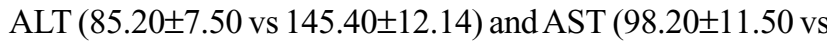
$310.10 \pm 17.50)$. Previous reports showed that STZ markedly increased the serum level of glucose. ${ }^{10}$ Montilla et $\mathrm{al}^{10}$ have reported that hyperglycemia can cause injuries in tissues and brain which subsequently may increase glucose excretion. Hypertriglyceridemia and hypercholesterolemia are known as the most common lipid abnormalities in diabetes ${ }^{11}$ and are related to glucose intolerance. ${ }^{12}$ It is well known that oxidative stress and reactive oxygen species production can degrade lipids and cause lipid peroxidation and lipolysis. Oxidative stress contributes to many pathological conditions and diseases, including cancer, neurological disorders, atherosclerosis, hypertension, ischemia and diabetes. ${ }^{13}$ Studies have reported that diabetes increases levels of ALT and AST in serum ${ }^{30}$ and kidney. ${ }^{31}$ Okada et $\mathrm{al}^{32}$ have reported that AST activity was significantly lower in diabetic rat tissues, because of inactivation of cytosolic AST in the diabetic rat tissues by a glycation reaction and/or by faulty glucose utilization in STZ induced diabetes. In contrast to our findings, Khan et $\mathrm{a}^{33}$ have reported that dietary inclusion of microalgae did not change ALT and AST concentration in male rats. Our findings showed that higher levels of SPM decreased the plasma concentrations of cholesterol, triglycerides, LDL-C, glucose, ALT and AST. The oxygen species, as oxidants, are responsible for increased lipids and glucose. Antioxidants may interact with oxidants and thus alleviate their negative effects on lipid parameters, glucose concentration and liver enzymes. MDA is an index for lipid peroxidation and our findings showed (Table 4) that it was significantly decreased in SD20 and SD30. As Table 4 shows, oral supplementing with SPM at higher levels increased antioxidant enzymes in liver. It seems that the increased levels of antioxidants interact with oxidants and partly alleviate negative effects of diabetes on lipids, glucose and liver enzymes. We believed that higher levels of SPM may provide essential TMs for synthesis of antioxidant enzymes, and, on the other hand, the increased levels of antioxidants decrease the plasma concentrations of glucose, lipid parameters, and liver enzymes and MDA. The role of some TMs in lowering glucose levels may be another reason for the reduced glucose, because higher levels of SPM increased some TMs. Interestingly, SPM had no significant effect on TM levels, antioxidant levels and blood biochemical parameters in healthy rats. In addition, our findings showed that SPM (20 and $30 \mathrm{mg} / \mathrm{kg}$ body weight) significantly alleviated adverse effects of diabetes on TNF- $\alpha$ and IL-6. These cytokines play significant roles in the pathogenesis of diabetes. It has been reported that diabetes increases levels of inflammatory cytokines. ${ }^{6}$ Overproduction of ROS increases oxidative stress and inflammatory responses. ${ }^{34} \mathrm{~A}$ study has shown that SPM reversed increased proinflammatory cytokines in the cerebellum, such as TNF- $\alpha$ and TNF- $\beta .{ }^{17}$ It seems that SPM shows anti-inflammatory effects by reducing ROS. This means that SPM decreases pro-inflammatory cytokines by antioxidant properties. Our findings showed that SPM increased anti-inflammatory responses as it increased antioxidant properties, implying a positive correlation between antioxidant and anti-inflammatory properties in SPM. In summary, an overdose of TMs may have negative effects on animals' heath; however, we did not observe toxicity effects of SPM at these levels on animals.

\section{Conclusion}

Our findings showed that diabetes significantly decreased the plasma concentration of TMs and antioxidant enzymes and also increased the plasma concentration of glucose, lipid parameters, MDA, ALT, AST, TNF- $\alpha$ and IL-6. Our results showed that oral supplementing with SPM, at high levels (20 and $30 \mathrm{mg} / \mathrm{kg}$ body weight), increased the plasma concentration of zinc, iron, selenium and copper. The higher levels of SPM (20 and $30 \mathrm{mg} / \mathrm{kg}$ body weight) also increased the plasma antioxidant enzymes and also lowered the plasma concentration of glucose, lipid parameters, MDA, ALT, AST, TNF- $\alpha$ and IL-6. It seems that oral supplementing of SPM (20 and $30 \mathrm{mg} / \mathrm{kg}$ body weight) may supply essential TMs for synthesis of antioxidant enzymes; on the other hand, increased levels of antioxidants enzymes can decrease MDA and the plasma concentration of lipids, glucose, MDA, ALT, AST, TNF- $\alpha$ and IL-6. It can be suggested to use SPM at higher levels as a supplement for treatment of diabetes. Since levels of 20 and $30 \mathrm{mg} / \mathrm{kg}$ had similar effects on mentioned parameters, we recommend using $20 \mathrm{mg} / \mathrm{kg}$, because of 
the lower cost. In addition, TMs have higher costs and may have toxicity effects in comparison to SPM. Thus, it can be recommended to use SPM instead of TMs.

\section{Author contributions}

All authors contributed toward data analysis, drafting and revising the paper and agree to be accountable for all aspects of the work.

\section{Disclosure}

The authors report no conflicts of interest in this work.

\section{References}

1. Murray RK, Granner D, Mayes P, Rodwell V. Harper's Biochemistry. 25th international ed. New York: Appleton and Lange; 2000.

2. Powers MA. Handbook of Diabetes Nutritional Management. Vol. 195. Frederick, MD: Aspen Publishers, Inc.; 1987.

3. Chausmer AB, Zinc CAB. Zinc, insulin and diabetes. J Am Coll Nutr. 1998;17(2):109-114.

4. Nielsen FH. New essential trace elements for the life sciences. Biol Trace Elem Res. 19901990;26-27(1):599-611.

5. Nerlich AG, Sauer U, Kolm-Litty V, Wagner E, Koch M, Schleicher ED. Expression of glutamine:fructose-6-phosphate amidotransferase in human tissues: evidence for high variability and distinct regulation in diabetes. Diabetes. 1998;47(2):170-178.

6. Donath MY, Shoelson SE. Type 2 diabetes as an inflammatory disease. Nat Rev Immunol. 2011;11(2):98-107.

7. Candilish DJ. Minerals. J Am Coll Nutr. 2000;17:286-310.

8. Resnick LM, Gupta RK, Bhargava KK, Hgruenspan H, Alderman $\mathrm{MH}$, Larag J. Magnesium deficiency in diabetes. Hypertension. 1991;17:951-957.

9. Wang ZQ, Zhang XH, Russell JC, Hulver M, Cefalu WT. Chromium picolinate enhances skeletal muscle cellular insulin signaling in vivo in obese, insulin-resistant JCR:LA-cp rats. J Nutr. 2006;136(2):415-420.

10. Montilla P, Barcos M, Munoz MC, Bujalance I, Munoz-Castaneda JR, Tunez I. Red wine prevents brain oxidative stress and nephropathy in streptozotocin-induced diabetic rats. J Biochem Mol Biol. 2005;38(5):539-544.

11. Khan BA, Abraham A, Leelamma S. Hypoglycemic action of Murraya koenigii (curry leaf) and Brassica juncea (mustard): mechanism of action. Indian J Biochem Biophys. 1995;32(2):106-108.

12. Ginsberg HN. Lipoprotein metabolism and its relationship to atherosclerosis. Med Clin North Am. 1994;78(1):1-20.

13. Rolo AP, Palmeira CM. Diabetes and mitochondrial function: role of hyperglycemia and oxidative stress. Toxicol Appl Pharmacol. 2006;212(2):167-178.

14. Bukan N, Sancak B, Yavuz O, et al. Lipid peroxidation and scavenging enzyme levels in the liver of streptozotocin-induced diabetic rats. Indian J Biochem Biophys. 2003;40(6):447-450.

15. Oliveira Maclde, Monteiro MPC, Robbs PG, Leite SGF. Growth and chemical composition of Spirulina maxima and Spirulina platensis biomass at different temperatures. Aquacult Int. 1999;7(4):261-275.
16. Burja AM, Banaigs B, Abou-Mansour E, Grant Burgess J, Wright PC. Marine cyanobacteria - a prolific source of natural products. Tetrahedron. 2001;57(46):9347-9377.

17. Deng R, Chow TJ, Hypolipidemic CTJ. Hypolipidemic, antioxidant, and antiinflammatory activities of microalgae Spirulina. Cardiovasc Ther. 2010;28(4):e33-e45.

18. AOAC. Official Methods of Analysis. 15th ed. Arlington: Association of Official Analytical Chemists; 1990.

19. Armstrong D, Al-Awadi F. Lipid peroxidation and retinopathy in streptozotocin-induced diabetes. Free Radic Biol Med. 1991;11(4): 433-436.

20. Roth H-P, Kirchgessner M. Zinc and insulin metabolism. Biol Trace Elem Res. 1981;3(1):13-32.

21. Singh RB, Niaz MA, Ahmad S, Rastogi SS, Singh U, Agarwal P. Dietary and serum levels of antioxidant minerals in patients with acute myocardial infarction. Trace Elem Electrol. 1995;12:148-152.

22. Chen MD, Liou SJ, Lin PY, Yang VC, Alexander PS, Lin WH. Effects of zinc supplementation on the plasma glucose level and insulin activity in genetically obese (ob/ob) mice. Biol Trace Elem Res. 1998;61(3):303-311.

23. Ravina A, Slezak L, Rubal A, Mirsky N. Clinical use of trace element chromium (III) in the treatment of diabetes mellitus. J Trace Elem Exp Med. 1995;8:183-190.

24. Cefalu WT, Bell-Farrow AD, Stegner J, et al. Effect of chromium picolinate on insulin sensitivity in vivo. J Trace Elem Exp Med. 1999;12(2):71-83.

25. Ravina A, Slezak L, Mirsky N, Bryden NA, Anderson RA. Reversal of corticosteroid-induced diabetes mellitus with supplemental chromium. Diabet Med. 1999;16(2):164-167.

26. Zargar AH, Shah NA, Masoodi SR, et al. Copper, zinc, and magnesium levels in non-insulin dependent diabetes mellitus. Postgrad Med J. 1998;74(877):665-668.

27. Viktorinova A, Toserova E, Krisko M, Durackova Z. Altered metabolism of copper, zinc and magnesium is associated with increased levels of glycated hemoglobin in patients with diabetes mellitus. Metabolism. 2009;58:1477-1482.

28. Battin EE, Brumaghim JL. Antioxidant activity of sulfur and selenium: a review of reactive oxygen species scavenging, glutathione peroxidase, and metal-binding antioxidant mechanisms. Cell Biochem Biophys. 2009;55(1):1-23.

29. Tapiero H, Townsend DM, Tew KD. The antioxidant role of selenium and seleno-compounds. Biomed Pharmacother. 2003;57(3-4):134-144.

30. Sublette ME, Ellis SP, Geant AL, Mann JJ. Meta-analysis of the effects of eicosapentaenoic acid (EPA) in clinical trials in depression. J Clin Psychiatry. 2011;72(12):1577-1584.

31. Yanardag R, Simmon L, Wolf A. Hypoglycemic activity of insulin in STZ induced diabetic rats; 1999. Available from: http://www.diabetes. org/living-with-diabetes/treatment-and-care/blood-glucose-control/ hypoglycemia-low-blood.html?loc=lwd-slabnav.

32. Okada M, Murakami Y, Miyamoto E. Glycation and inactivation of aspartate aminotransferase in diabetic rat tissues. J Nutr Sci Vitaminol. 1997;43(4):463-469.

33. Khan M, Shobha JC, Mohan IK, Rao Naidu MU, Prayag A, Kutala VK. Spirulina attenuates cyclosporine-induced nephrotoxicity in rats. J Appl Toxicol. 2006;26(5):444-451.

34. Dhalla NS, Temsah RM, Netticadan T. Role of oxidative stress in cardiovascular diseases. J Hypertens. 2000;18(6):655-673.

Diabetes, Metabolic Syndrome and Obesity: Targets and Therapy

Publish your work in this journal

Diabetes, Metabolic Syndrome and Obesity: Targets and Therapy is an international, peer-reviewed open-access journal committed to the rapid publication of the latest laboratory and clinical findings in the fields of diabetes, metabolic syndrome and obesity research. Original research, review, case reports, hypothesis formation, expert

\section{Dovepress}

opinion and commentaries are all considered for publication. The manuscript management system is completely online and includes a very quick and fair peer-review system, which is all easy to use. Visit http://www.dovepress.com/testimonials.php to read real quotes from published authors. 